Saher S Gasgoos

BDS, MSc (Assist Lect)

\section{Periodontal health care by people of Humaidat village in Ninevah}

\author{
Department of Pedod, Orthod and Prev Dent
}

College of Dentistry, University of Mosul

\begin{abstract}
This study was a part of a field work carried out by the University of Mosul in Humaidat village which is located at the Tigris river about $25 \mathrm{~km}$ to the northern west from Mosul. The size of the sample was 213 individuals; 105 males and 108 females. Their ages were ranged between $10-59$ years.

Clinical dental examination was carried out using plaque index (Pl I), gingival index (GI) and calculus index (CI). Questionnaires were used to assess the level of dental health attitude and behaviour among the individuals.

Results showed that a large percent of them do not brush their teeth (46.4\%) and do not use interdental cleaning aids $(87.3 \%)$. Also a large percent of them did not attend a dental treatment previously (45\%), and most of dental attendances of the others were for teeth extraction and due to pain.

Clinical examination showed that the mean scores for plaque, gingival and calculus indices were high $(1.16,1.22$ and 0.54 respectively) and increased by increasing age.
\end{abstract}

Key Words: Gingival health status, attitude, behaviour.

$$
\begin{aligned}
& \text { أجريـت هذه الدراسـة كجزء مـن الممارســة } \\
& \text { الميدانية التي قامت بها جامعة الموصل في قرية } \\
& \text { الحميدات التي تقع على نهر دجلة حوالي ه كم } \\
& \text { شمال غرب الموصل. تم إجراء مسح صحي على إلى }
\end{aligned}
$$

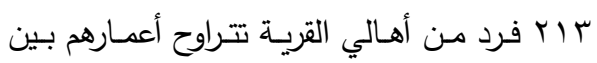

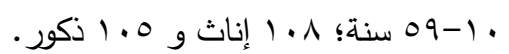

$$
\begin{aligned}
& \text { اجري الفحص السـريري باسـتخدام مؤشـر }
\end{aligned}
$$

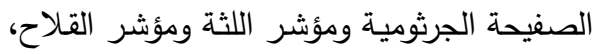

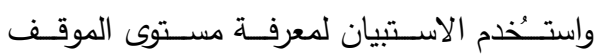

$$
\begin{aligned}
& \text { والسلوك الصحي الفموي للأفراد. } \\
& \text { أظهرت النتائج أن نسبة كبيرة مـن أهـالي لافرون }
\end{aligned}
$$

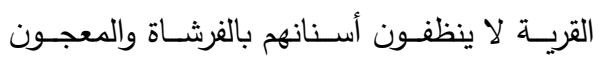

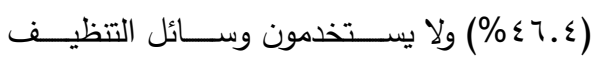

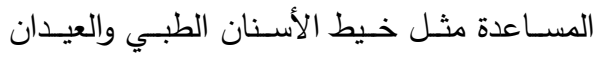

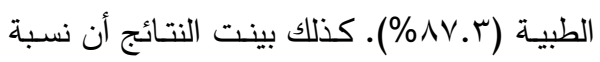

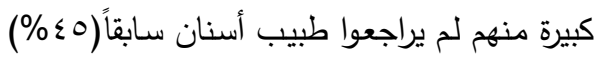

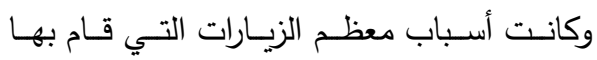

$$
\begin{aligned}
& \text { الآخرون لطبيب الأسنان هي قلـع الأسنان وألم }
\end{aligned}
$$

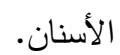

$$
\begin{aligned}
& \text { أظهرت نتائج الفحص السريري أن معدل }
\end{aligned}
$$

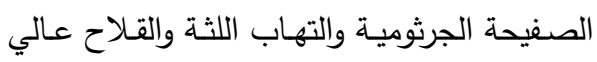

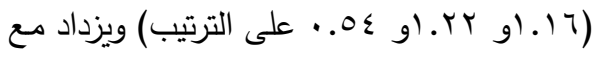

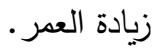

\section{INTRODUCTION}

There are several diseases which affect the gingiva and the bone supporting the teeth. Most of the individuals who have some natural teeth have chronic periodontal disease. This may be confined to the gingiva or may involve the deeper supporting tissue including the bone. ${ }^{(1)}$ The progressive destruction of connective tissue and bone occurs only in areas exhibiting gingivitis. This, however, does not suggest that all gingivitis proceed to periodontitis. ${ }^{(2,3)}$

Periodontal disease is caused by dental plaque, which builds upon the tooth 
especially around the gingival margins. ${ }^{(4)}$ The most effective means of promoting oral health are those health care practices performed by people themselves with tooth brushing which being cited as the most appropriate oral hygiene habit. ${ }^{(5)}$ Regular daily removal of plaque by tooth brushing and using of interdental cleaning aids is essential part of oral hygiene practice. This can prevent periodontal disease. ${ }^{(4)}$

The aims of the study are to evaluate gingival health, plaque and calculus accumulation among the individuals and the level of dental health attitude and behaviour among them.

\section{SAMPLE AND METHODS}

This study was carried out in Humaidat village which is located at Tigris river about $25 \mathrm{~km}$ to the northern west from Mosul. The size of the sample was 213 individual; 108 females and 105 males (Table 1). Their ages were ranged between 10-59 years. These individuals were visi-ted at their houses, and questionnaires were filled by the researcher and a number of dental students who participated in the study. The questionnaires included a num-ber of questions related to dental health attitude and behaviours.

Table (1): Number and distribution of the individuals

\begin{tabular}{cccc}
\hline $\begin{array}{c}\text { Age } \\
\text { Group }\end{array}$ & Males & Females & Total \\
\hline $\mathbf{1 0}-\mathbf{1 9}$ & 75 & 30 & 105 \\
$\mathbf{2 0}-\mathbf{2 9}$ & 15 & 21 & 36 \\
$\mathbf{3 0}-\mathbf{3 9}$ & 6 & 21 & 27 \\
$\mathbf{4 0 - 4 9}$ & 6 & 27 & 33 \\
$\mathbf{5 0}-\mathbf{5 9}$ & 3 & 9 & 12 \\
\hline Total & 105 & 108 & 213 \\
\hline
\end{tabular}

The same individuals were examined clinically under natural daylight to evaluate the amount of accumulated plaque, gingivitis and calculus. Instruments used were plane mouth mirror, WHO periodontal probe, cotton and disinfectant solution.

\section{Indices}

Indices used in the clinical examination were:

1) Plaque Index: according to the method reported by Silness and Löe (1964). ${ }^{(6)}$

2) Gingival Index: according to the method reported by Löe and Silness (1963). ${ }^{(7)}$

3) Calculus Index: according to the method reported by Greene and Vermillion (1964). ${ }^{(8)}$

\section{Selection of Teeth}

The teeth selected were $(16,12,24$, $36,32,44)$. Deciduous and adjacent permanent teeth were used to substitute the unerupted or missing teeth. For each tooth, the buccal and lingual surfaces were examined.

\section{Analysis of Data}

Analysis of the data includes calculation of mean scores for the three indices and calculation of percentage for the answers of the questionnaires.

\section{RESULTS AND DISCUSSION}

Data were collected from 213 individuals who were divided into five groups according to their ages (Table 1). The young age group was reported higher percent than the older ages. Males were less in number than females; this is due to the fact that the older ages especially males were busy in their work at time of the examination.

\section{Teeth Brushing Practice}

From the questionnaires, the results show that $46.4 \%$ of all age groups did not brush their teeth, and $35.2 \%$ brushed their teeth infrequently (Table 2); while the percentage of once daily brushing was $14.2 \%$ and only $4.2 \%$ twice daily brushing. This indicated the poor awareness among them regarding oral health. The young age group (10-19 years) brush more regularly and more frequently than other age groups because this age group care more about their health and appearance. ${ }^{(9)}$ These results were close to other studies carried out in Kasa Fakhra and Shamsiat 
villages, Sharkhan village, and Hammam Al-Allil village. ${ }^{(10,11,12)}$

When comparing this result with other studies carried out in developed countries as in England, once daily teeth brushing in young ages were $64 \%{ }^{(13)}$ $88 \%{ }^{(14)}$ and $92 \% .^{(15)}$

Table (2): Tooth brushing practice

\begin{tabular}{ccccc}
\hline $\begin{array}{c}\text { Age } \\
\text { Group }\end{array}$ & $\begin{array}{c}\text { Not } \\
\text { Brush }\end{array}$ & Infrequently & $\begin{array}{c}\text { Once } \\
\text { Daily }\end{array}$ & $\begin{array}{c}\text { Twice } \\
\text { Daily }\end{array}$ \\
\hline $\mathbf{1 0}-\mathbf{1 9}$ & $51.4 \%$ & $17.1 \%$ & $22.8 \%$ & $8.5 \%$ \\
$\mathbf{2 0}-\mathbf{2 9}$ & $16.6 \%$ & $83.3 \%$ & $0.0 \%$ & $0.0 \%$ \\
$\mathbf{3 0 - 3 9}$ & $33.3 \%$ & $66.6 \%$ & $0.0 \%$ & $0.0 \%$ \\
$\mathbf{4 0 - 4 9}$ & $63.6 \%$ & $18.1 \%$ & $18.1 \%$ & $0.0 \%$ \\
$\mathbf{5 0 - 5 9}$ & $75 \%$ & $25 \%$ & $0.0 \%$ & $0.0 \%$ \\
\hline Total & $46.4 \%$ & $35.2 \%$ & $14.2 \%$ & $4.2 \%$ \\
\hline
\end{tabular}

Regarding the source of learning tooth brushing practice, it was shown that the family has a major role in learning this habit $(71.2 \%)$ (Table 3 ), and this is called primary socialization, which means that the father and mother and also the brothers and sisters have direct effect on learning good habits on the family members. Also the school and teachers were shown to have the second source of learning brushing habit $(23.6 \%)$ which is called secondary socialization, while the television and dentist have a very little effect. This is due to that a large percent of them did not attend a dental clinic before.

The percent of learning brushing practice from parents in this study is larger than other studies in other villages. $(10,11)$

Table (3): Source of learning tooth brushing practice

\begin{tabular}{cccc}
\hline Family & School & Television & Dentist \\
\hline $71.2 \%$ & $23.6 \%$ & $2.6 \%$ & $2.6 \%$ \\
\hline
\end{tabular}

About the reasons of not brushing the teeth, Table (4) showed that a large percent of them $(36.4 \%)$ stated that the occurrence of gingival bleeding during brushing is the main cause of stopping brushing, followed by $33.3 \%$ stated that they have no tooth brush and tooth paste; while $18.2 \%$ added that they do not know how to brush their teeth, and $12.1 \%$ stated that they have no sufficient time to do that.

Regarding the use of interdental cleaning aids (tooth picks, dental floss and mouth gargle); $87.3 \%$ of them said that they do not use it neither following teeth brushing nor separately. Only $8.4 \%$ of them use tooth picks and $4.2 \%$ use mouth gargle; while nobody uses dental floss.

\section{Dental Attendance}

From Table (5), a large percent of the individuals $(45 \%)$ did not attend a dental clinic previously although most of them were affected by gingivitis and dental caries. $(29.6 \%)$ of dental attendance of the remaining individuals were before one year, and $21.1 \%$ of the attendances were during this year. This indicated their ignorance of their oral health. The percentage of attendances increased with increasing age which is due to increasing the severity of gingivitis and dental caries, which is usually associated with pain and discomfort.

Table (4): Causes of not brushing the teeth

\begin{tabular}{ccccc}
\hline $\begin{array}{c}\text { Age } \\
\text { Group }\end{array}$ & $\begin{array}{c}\text { Have } \\
\text { No } \\
\text { Time }\end{array}$ & $\begin{array}{c}\text { Have No } \\
\text { Tooth Brush }\end{array}$ & $\begin{array}{c}\text { Do not } \\
\text { Know }\end{array}$ & $\begin{array}{c}\text { Gingival } \\
\text { Bleeding }\end{array}$ \\
\hline $\mathbf{1 0}-\mathbf{1 9}$ & $5.6 \%$ & $44.4 \%$ & $11.1 \%$ & $38.9 \%$ \\
$\mathbf{2 0}-\mathbf{2 9}$ & $50 \%$ & $0.0 \%$ & $0.0 \%$ & $50 \%$
\end{tabular}




\begin{tabular}{ccccc} 
30-39 & $0.0 \%$ & $25 \%$ & $25 \%$ & $50 \%$ \\
$\mathbf{4 0 - 4 9}$ & $28.6 \%$ & $28.6 \%$ & $14.2 \%$ & $28.6 \%$ \\
$\mathbf{5 0 - 5 9}$ & $0.0 \%$ & $0.0 \%$ & $66.7 \%$ & $33.3 \%$ \\
\hline Total & $12.1 \%$ & $33.3 \%$ & $18.2 \%$ & $36.4 \%$ \\
\hline \multicolumn{5}{c}{ Table (5): Dental attendance } \\
\hline Age & Not & During & During & Before \\
Group & Visit & Monis & This & One \\
& Year & Year \\
\hline 10-19 & $74.2 \%$ & $0.0 \%$ & $17.1 \%$ & $8.5 \%$ \\
$\mathbf{2 0 - 2 9}$ & $8.3 \%$ & $8.3 \%$ & $50 \%$ & $33.3 \%$ \\
$\mathbf{3 0 - 3 9}$ & $11.1 \%$ & $22.2 \%$ & $0.0 \%$ & $66.6 \%$ \\
$\mathbf{4 0 - 4 9}$ & $36.3 \%$ & $0.0 \%$ & $27.2 \%$ & $36.3 \%$ \\
$\mathbf{5 0 - 5 9}$ & $0.0 \%$ & $0.0 \%$ & $0.0 \%$ & $100 \%$ \\
\hline Total & $45 \%$ & $4.3 \%$ & $21.1 \%$ & $29.6 \%$ \\
\hline
\end{tabular}

Table (6) showed the causes of dental attendance; $59 \%$ were for tooth extraction, $20.5 \%$ due to pain, $15.4 \%$ for restoration and only $5.1 \%$ for scaling and polishing. This result is close to other studies carried out in other villages. ${ }^{(10,11,16)}$

Table (7) showed the reasons of not attending dental treatment. About $75 \%$ of the individuals in all age groups stated that they do not need dental treatment because they believe that their teeth and gingivae are healthy, $2.8 \%$ said that there is no near dental clinic or health center; while $13.9 \%$ stated that the fear from pain during treatment is the main cause. The high cost of dental treatment included $8.3 \%$ of their answers.

Table (6): Reasons of dental attendance

\begin{tabular}{cccccc}
\hline $\begin{array}{c}\text { Age } \\
\text { Group }\end{array}$ & Extraction & Restoration & $\begin{array}{c}\text { Scaling \& } \\
\text { Polishing }\end{array}$ & Pain & Prosthetic \\
\hline $\mathbf{1 0}-\mathbf{1 9}$ & $55.6 \%$ & $11.1 \%$ & $0.0 \%$ & $33.3 \%$ & $0.0 \%$ \\
$\mathbf{2 0}-\mathbf{2 9}$ & $54.5 \%$ & $27.3 \%$ & $9 \%$ & $9 \%$ & $0.0 \%$ \\
$\mathbf{3 0}-\mathbf{3 9}$ & $75 \%$ & $12.5 \%$ & $0.0 \%$ & $12.5 \%$ & $0.0 \%$ \\
$\mathbf{4 0 - 4 9}$ & $57.1 \%$ & $0.0 \%$ & $14.3 \%$ & $28.6 \%$ & $0.0 \%$ \\
$\mathbf{5 0 - 5 9}$ & $50 \%$ & $25 \%$ & $0.0 \%$ & $25 \%$ & $0.0 \%$ \\
\hline Total & $59 \%$ & $15.4 \%$ & $5.1 \%$ & $20.5 \%$ & $0.0 \%$ \\
\hline
\end{tabular}

Table (7): Reasons of not attending dental treatment previously

\begin{tabular}{ccccc}
\hline $\begin{array}{c}\text { Age } \\
\text { Group }\end{array}$ & $\begin{array}{c}\text { Do Not } \\
\text { Need }\end{array}$ & $\begin{array}{c}\text { No } \\
\text { Near } \\
\text { Clinic }\end{array}$ & $\begin{array}{c}\text { Fear } \\
\text { From } \\
\text { Pain }\end{array}$ & $\begin{array}{c}\text { Cost } \\
\text { Factor }\end{array}$ \\
\hline $\mathbf{1 0}-\mathbf{1 9}$ & $76.9 \%$ & $3.9 \%$ & $19.2 \%$ & $0.0 \%$ \\
$\mathbf{2 0}-\mathbf{2 9}$ & $66.7 \%$ & $0.0 \%$ & $0.0 \%$ & $33.3 \%$ \\
$\mathbf{3 0 - 3 9}$ & $66.7 \%$ & $0.0 \%$ & $0.0 \%$ & $33.3 \%$ \\
$\mathbf{4 0 - 4 9}$ & $75 \%$ & $0.0 \%$ & $0.0 \%$ & $25 \%$ \\
$\mathbf{5 0 - 5 9}$ & $0.0 \%$ & $0.0 \%$ & $0.0 \%$ & $0.0 \%$ \\
\hline Total & $75 \%$ & $2.8 \%$ & $13.9 \%$ & $8.3 \%$ \\
\hline
\end{tabular}

\section{Clinical Examination}

\section{Dental Plaque}

Table (8) showed the mean plaque index score for all age groups. The less mean scores (0.98) was at the age group 
10-19 years which increased by increasing age.

The mean plaque scores for the persons in this study was 1.16 which is less than that recorded by other studies. ${ }^{(10,11,16)}$

Table (8): Mean plaque, gingival and calculus indices scores

\section{Al-Rafidain Dent J}

Vol. 3, No. 1, 2003

\begin{tabular}{cccc} 
Age & $\begin{array}{c}\text { Plaque } \\
\text { Index }\end{array}$ & $\begin{array}{c}\text { Gingival } \\
\text { Index }\end{array}$ & $\begin{array}{c}\text { Calculus } \\
\text { Index }\end{array}$ \\
\hline Group & 1.06 & 0.16 \\
$\mathbf{1 0}-\mathbf{- 1 9}$ & 0.98 & 1.06 & 0.42 \\
$\mathbf{2 0 - 2 9}$ & 1.1 & 1.22 & 0.43 \\
$\mathbf{3 0 - 3 9}$ & 1.19 & 1.4 & 0.47 \\
$\mathbf{4 0 - 4 9}$ & 1.59 & 1.51 & 1.1 \\
$\mathbf{5 0 - 5 9}$ & 1.6 & 1.52 & 0.54 \\
\hline Total & 1.16 & 1.22 & \\
\hline
\end{tabular}

\section{Gingival Health Examination}

Table (8) showed the mean gingival index scores for all age groups. The less mean scores (1.06) was recorded at the age group 10-19 years which increased by increasing age. It has been shown from the clinical examination that $91.5 \%$ of the individuals have gingival bleeding during probing (score 2) at more than four surfaces of the examined teeth, and only $8.4 \%$ of them have mild gingivitis; while nobody of them has a score (3) at any surface.

The mean gingival index score in this study is more than that reported by other study. ${ }^{(16)}$

\section{Calculus Examination}

The study reported that $39.4 \%$ of the persons examined were free from calculus accumulation on their teeth; while in the others, the mean calculus index scores increased from 0.16 at age group 10-19 years to reach 1.1 at age group 50-59. Therefore, the mean score for all individuals was 0.54 . Only $5.6 \%$ of them have a score (3) calculus accumulation at some surfaces of the examined teeth.

\section{REFERENCES}

1. Health Education Council (HEC). The scientific basis of dental health education. $\mathrm{Br}$ Dent J. 1979; 16: 51-54.

2. Harald LE. Periodontal disease as we approach the year 2000. J Periodontol. 1994; May: 464-467.

3. Fishwick MR, Ashley FP, Wilson RF. Can a workplace preventive programme affect periodontal health? Br Dent J. 1998; 184(6): 290-293.

4. Leatherman GH. Oral hygiene for children: A look at what we must have and what we should do. Int Dent J. 1982; 32(3): 252-258.

5. Honkala E. Oral health promotion with children and adolescents. In: Shou L, Blinkhorn AS (eds): Oral Health Promotion. Oxford, Oxford University Press, UK. 1993; Pp: 169187.

6. Silness P, Löe H. Periodontal disease in pregnancy. Correlation between oral hygiene and periodontal condition. Acta Odontol Scand. 1964; 22: 121-135.

7. Löe H, Silness P. Periodontal disease in pregnancy. Prevalence and severity. Acta Odontol Scand. 1963; 21: 533-551.

8. Greene JC, Vermillion JR. The simplified oral hygiene index. J Am Dent Assoc. 1964; 68: 7. 
9. Gasgoos SS. The effectiveness of different methods of teaching dental health on the incidence of plaque and gingivitis in 12-15 years old students. MSc Thesis. College of Dentistry. University of Mosul. 2001.

10. Khamrco TY, Abdal AK, Al-Salman KhA. Dental health status in Kasa Fakhra and Shamsiat village, Mosul. J Coll Dent. 2000; 7: 5-18.

11. Khamrco TY, Abdal AK. Dental health status in Sharkhan village, Mosul. University of Mosul. 1988.

12. Khamrco TY. Dental health status in Hammam Al-Allil village, Mosul. University of Mosul. 1992.

13. McHugh W, McEwan J, Hitchen A. Dental disease and related factors in 13 years old children in Dundee. Br Dent J. 1964; 117: 246-253.

14. Sheiham A. The prevalence and severity of periodontal disease in Vorvey No Nohool 2003 children. Dent Prac. 1969; 19: 232-238.

15. Todd J. Children dental health in England and Wales 1973. HMSO, London. 1975.

16. Khamrco TY, Al-Salman KhA, Abdal AK. Dental health status in Humaidat village. Iraqi Dent J. 1998; 23: 3-22.

Received: $30 / 11 / 2002$

Accepted for Publication: 7/7/2003 